\title{
Validity and Reliability of Charlson Comorbidity Index (CCI) among Iranian Community-Dwelling Older Adults
}

\author{
Raziye Sadat Hosseini ${ }^{1}$, Yadollah Abolfathi Momtaz ${ }^{2,3}$, \\ Farahnaz Mohammadi Shahboulaghi ${ }^{2}$, Masoome Alijanpour Aghamaleki ${ }^{4}$ \\ ${ }^{1}$ Nursing Care Research Center, School of Nursing And Midwifery, I. R. Iran \\ University of Medical Sciences, Tehran, I. R. Iran \\ 2Iranian Research Center on Aging, University of Social Welfare and Rehabilitation Sciences, Tehran, I. R. Iran \\ ${ }^{3}$ Malaysian Research Institute on Ageing (MyAgeing), Universiti Putra, Malaysia \\ ${ }^{4}$ PhD Student of Reproduction Health, Tarbiat Modares University, Tehran, I. R. Iran
}

\begin{abstract}
SUMMARY
Comorbidity Index (CCI) is a simple method for the demonstration of comorbidity burden. This study aimed to assess the validity and reliability of the CCI among Iranian community-dwelling older adults.

This cross-sectional study was carried out on a sample of 600 community-dwelling older adults aged 60 years and over in Tehran, Iran, 2017. A multistage clustered random sampling method was employed to obtain the sample. The CCI consisted of 17 categories of diseases, as a means of measuring one-year illness risks and their burden. The criterion validity was assessed with Self-Rated Health (SRH) and Activities of Daily Living (ADL) scale. To test the validity and reliability of the CCI, Spearman's rho correlation and the Intra-class Correlation Coefficient (ICC) were applied using SPSS version 23 software, respectively.

Out of 600 respondents, $64.0 \%$ were female. The sample mean age was $76.82(\mathrm{SD}=7.45)$ years, and nearly $63 \%$ were married. The results of criterion validity using multiple linear regression analysis showed that the CCI was significantly predicted by SRH (Beta $=-0.26, p<0.001$ ) and ADL (Beta $=-0.17, p<0.001$ ). Additionally, the reliability of the CCI, using the Intra-class Coefficient Correlation, was found to be 0.77; $95 \%$ CI, 0.60 to 0.87 .

As the results showed a good level of validity and reliability of the CCI, its use is therefore suggested in health surveys among Iranian community-dwelling older adults.

Key words: Charlson Comorbidity Index, criterion validity, reliability, community-dwelling older adults, Iran

Corresponding author:

Farahnaz Mohammadi Shahboulaghi

E-mail: mohammadifarahnaz@gmail.com
\end{abstract}




\section{INTRODUCTION}

Population aging is a growing phenomenon throughout the world. In 2017, it was estimated that $13 \%$ (about 962 million) of the people were aged 60 years or over in the world, and it is projected to reach over $25 \%$ in 2050 (1). In reviewing the old age changes in the world, it is clear that Asian countries are faced with a faster growth in aging (2).This is apparent in comparison to the results of the censuses carried out recently in Iran. The results of the census of 2011 in Iran showed that $8.2 \%$ of the population were older adults (3), while this ratio increased to $9.3 \%$ in 2016 (4). This population shift and also demographic changes will lead to a higher rate of elderly-aged people in the future (5). Therefore, population aging and health and long-term care issues are becoming imperative (6).

Although age and life expectancy are the consequences of a good level of health (7), aging is associated with physical, social, and mental changes (8). These alterations include increased risk of chronic physical and mental disease, disability (9), retirement and loss of occupational roles, and the reduction of individual social contacts and networks (10), all of which lead to a decreased quality of life in elderly population (11). In most societies, psychological and cognitive deficiencies are the causes of greater dependency on formal or informal support for older adult health, performance, and self-sufficiency (12), which cause health issues and long-term care to become more important (13). Overall, measuring health and its components is one of the most important issues for older adults and researchers (14). During the aging process, a series of internal and external changes occur that lead to alterations in the functions of an individual's organs and systems. These changes increase the possibility of organ failure or disease (15).

Several studies have shown that in older adults, many factors such as the diagnosis of a disease, the number of conditions that the elderly suffer from (comorbidity), and the elderly's performance status are known as mortality predictors (16). Therefore, it is imperative to have information about the comorbidity in older adults as a predictor of the health status (17) Comorbidity, which impacts the contemporary clinical practice and research, is a major consideration in health systems and funding models. However, there is a lack of consensus on the most effective method for measuring comorbidity (18).

Additionally, it is hard for older adults to recall their illnesses or information about their hospitalization for a long time. In fact, they may be tired or unable to complete long questions and inventories (20). Another problem for assessing the health status is that questioners themselves need to be educated or at least have previous training in the field of medical well-being $(16,19)$.

In epidemiological studies, it is very important to have an accurate method for measuring comorbidity in older adults (20). To determine the statistics of comorbidity, several tools have been used in a variety of populations. For example, the Cumulative Illness Rating Scale (CIRS) was validated by Hudon et al. in 2005 (21). Indeed, the Chronic Disease Score (CDS) is a risk-adjustment metric based on age, gender, and the history of poly-pharmacy introduced by Clark et al. in 1995 (22). Both instruments are capable of simple measuring of comorbidity, but the most important defect in all of these instruments was the lack of attention to the detrimental effect of the disease on individual functions and the lack of severity of illness in all instruments (23).

In the studies about comorbidity, Charlson Comorbidity Index (CCI) considers the burden of illnesses with scoring their weight (24). This index was first introduced as a means of measuring oneyear illness risks and their burden by Charlson in 1984 (23). The original index had 19 categories of medical conditions. Then, it was modified to 17 categories by Romano, Roost (25) )1992(. The diabetes and liver disease have been considered as the most important categories of the new version of the CCI.

The burden of illness is scored 1, 2, 3, and 6, based on their severity and the mortality risk. Since this index is easy to use and has high power in predicting the mortality in older adults, it has been used in many studies (23). It may be able to improve epidemiological research in the future and the health care planning for older adults (26).

The CCI is also used in some studies in Iran (27), but there it has not been applied to assess its validity and reliability in older adults. Therefore, this study was conducted to determine the validity and reliability of the CCI in Iranian community-dwelling older adults. 


\section{PARTICIPANTS AND METHODS}

The current study used a cross-sectional design to assess the validity and reliability of the CCI among Iranian community-dwelling older adults. The study was conducted from July to November 2017. Six hundred community-dwelling older adults, 60 years of age or over in Tehran (the capital of Iran) have participated using a multistage clustered random sampling method. The ability to communicate verbally, not taking medications that affect the level of consciousness and no end-stage diseases were the inclusion criteria. Unwillingness to continue participating in the study, incomplete fulfillment of the questionnaires, and acute physical or psychological conditions during answering the questionnaires were the exclusion criteria for the study.

The sampling method was based on the geographic information system of Tehran and the rate of aging in Iran (about 10\%) (4). Tehran has 22 municipal districts and around 112 subdistricts. At the first phase of sampling process, six districts were randomly picked up. In the second phase, a subdistrict was randomly selected from each district as a cluster. From the selected regions, 100 samples participated randomly according to inclusion criteria. Sample selection continued until the number of participants in each neighborhood was adequate.

The data-collecting tools that were used in this study consist of demographic questions, the CCI, Self -Rated Health (SRH) measure, and the Activity Daily Living (ADL) scale. Two enumerators were trained regarding the questionnaires and randomly supervised during the completion, and appropriate support was provided when required. Data collection was conducted in respondents' homes by faceto-face interview techniques. In addition, the participants named their illnesses according to the $\mathrm{CCI}$ in order to answer the demographic information questions. The CCI consists of 17 categories of comorbidity and can predict the one-year mortality risk and burden of disease. Each condition (disease) was assigned with a score of 1, 2, 3, or 6 depending on the risk of mortality associated with the condition (28).

\section{Criterion validity}

To assess the validity of the CCI in this study, criterion validity was used. In psychometric properties, criterion validity is the scope that a measure is related(29). In fact, it refers to a condition where a tool replaces with another tool (30). Criterion validity is often divided intoconcurrent and predictive validity. Concurrent validity shows the relationship between the results from the tool studied and other variables that were collected at the same time (31). On the other hand, predictive validity compares the measure in question with an outcome assessed at a later time (32). In other words, predictive validity is the degree to which test scores predict performance on some future criterion (33).

In this study, the SRH was used to assess concurrent validity. In the SRH, participants were asked to rate their health status on a Likert scale ("5" excellent, "4" very good, "3" good, "2" fair, and "1" poor). A lower score of the SRH measure indicated a lower health status (34).

The Activities of Daily Living (ADL) scale was used to confirm the predictive validity of the CCI. The ADL is a set of basic activities performed by persons for independent living at home or in the community on a daily basis necessary (35). The Index of ADL was developed by Kats et.al in 1963 to study the results of treatment and prognosis in older adults and chronically ill people. Scores of the index were computed for the overall performance in dressing, bathing, going to the toilet, transferring, incontinence, and feeding (36). Many researchers used the index as a survey instrument, objective guide to the course of chronic illness, a tool for studying the aging process, and aid in rehabilitation teaching (37). Psychometric properties of the Persian version of the ADL were evaluated in Iran (38), wherein ADL index is a valid and reliable instrument for older adults (39). In order to investigate the CCI validity, the multiple linear regression analysis between the CCI, SRH, and ADL was examined.

\section{Reliability}

To assess the reliability of the CCI, a test-retest method was performed for only 51 of the study subjects. The test-retest reliability of a measure is an estimate of the repeatability of its results over time when no change in condition occurs (39). The test retest reliability signifies the internal validity of a test and ensures that the measurements obtained in one setting are both representative and stable over time (40). The distance should be such that the responders forget the phrases given in the questionnaire but the general study concept should not be forgotten (13). 
In the present study, the same enumerators asked participants to answer the CCI after 20 days again to examine the test-retest reliability. The researchers were ensured that the subject's health status was stable during this interval period. The subjects would be advised not to complete the retest questionnaires if they had an acute health condition.

\section{Data analysis}

Data were analyzed using the SPSS software version 23. Descriptive statistics such as percentages, means, standard deviations (SD), and range were used. To assess the concurrent and predictive validity of the CCI, the Spearman rho correlation coefficient was used. To examine the reliability of the CCI, a test-retest method was applied and the intraclass correlation coefficient (ICC) reported as the repeatability of the CCI.

\section{Ethical issues}

This study protocol was conducted in accordance with the guidelines in the Declaration of Helsinki, World Medical Association (WMA), and approved by the Medical Research Ethics Committee of the University of Social Welfare and Rehabilitation Sciences, Tehran, Iran. After explaining the study purpose, written informed consent was obtained from all participants who agreed to participate.

\section{RESULTS}

Six hundred community-dwelling older adults (63.7\% women) answered the questionnaires. The mean age was $76.82(\mathrm{SD}=7.45)$ years, and almost $47 \%$ of them were in the range of 75-84 years old. Around $63.0 \%$ of the study subjects were married and $48 \%$ of them were able to read and write. Nearly $25 \%$ of the total sample were retired approximately $10.5 \%$ of which were female. Table 1 shows the demographic characteristics of the study subjects.

The study results showed that the prevalence of comorbidity in older adults was $48 \%, 9 \%$ of which reported severe comorbidity. Indeed, only in five people SRH was excellent and in the majority of them (46.3\%), it was fair. Based on ADL, $72.5 \%$ of the study respondents were independent. Table 2 shows the frequency distribution of $\mathrm{CCI}, \mathrm{SRH}$, and $\mathrm{ADL}$ tools of the study sample.

Table 1. Demographic characteristics of the Iranian community-dwelling older adults

\begin{tabular}{|c|c|c|c|c|c|}
\hline Variables & Category & Frequency & Percentage & Mean & $\mathrm{SD}$ \\
\hline \multirow{3}{*}{ Age } & $60-74$ & 225 & 37.5 & \multirow{3}{*}{76.82} & \multirow{3}{*}{7.45} \\
\hline & $75-84$ & 283 & 47.2 & & \\
\hline & +85 & 92 & 15.3 & & \\
\hline \multirow{2}{*}{ Sex } & Male & 218 & 36.3 & & \\
\hline & Female & 382 & 63.7 & & \\
\hline \multirow{2}{*}{ Marital status } & Married & 379 & 63.1 & \multirow{2}{*}{ - } & \multirow{2}{*}{ - } \\
\hline & Unmarried & 221 & 36.9 & & \\
\hline \multirow{5}{*}{ Number of children } & 0 & 2 & 0.3 & \multirow{5}{*}{4.94} & \multirow{5}{*}{1.95} \\
\hline & $1-2$ & 40 & 6.7 & & \\
\hline & $3-5$ & 344 & 57.3 & & \\
\hline & $6-8$ & 184 & 30.7 & & \\
\hline & +9 & 30 & 5.0 & & \\
\hline \multirow{2}{*}{$\begin{array}{l}\text { Ability to read } \\
\text { and write }\end{array}$} & No & 314 & 52.3 & & \\
\hline & Yes & 286 & 47.7 & & \\
\hline \multirow{4}{*}{ Employment status } & Employed & 31 & 5.2 & \multirow{4}{*}{ - } & \multirow{4}{*}{ - } \\
\hline & Retired & 153 & 25.5 & & \\
\hline & Unemployed & 43 & 7.2 & & \\
\hline & House wife & 373 & 62.1 & & \\
\hline
\end{tabular}


Table 2. Frequency distribution of CCI, SRH and ADL tools of the Iranian community dwelling older adults

\begin{tabular}{|c|c|c|c|c|c|}
\hline Variables & Category & Frequency & Percentage & Mean & SD \\
\hline \multirow{4}{*}{ CCI } & 0 (no comorbidity) & 312 & 52 & \multirow{4}{*}{1.8} & \multirow{4}{*}{1.9} \\
\hline & 1-2 (mild comorbidity) & 133 & 22.1 & & \\
\hline & 3-4 (moderate comorbidity) & 100 & 16.7 & & \\
\hline & +5 (severe comorbidity) & 55 & 9.2 & & \\
\hline \multirow{5}{*}{ SRH } & 1 (Poor) & 127 & 21.2 & \multirow{5}{*}{2.17} & \multirow{5}{*}{0.84} \\
\hline & 2 (Fair) & 278 & 46.3 & & \\
\hline & 3 (Good) & 165 & 27.5 & & \\
\hline & 4 (Very good) & 25 & 4.2 & & \\
\hline & 5 (Excellent) & 5 & 0.8 & & \\
\hline \multirow{3}{*}{ ADL } & 0-6 (dependent) & 107 & 17.8 & \multirow{3}{*}{10.07} & \multirow{3}{*}{3.17} \\
\hline & 7-9 (help need) & 58 & 9.7 & & \\
\hline & 10-12 (independent) & 435 & 72.5 & & \\
\hline
\end{tabular}

Table 3.The results of multiple linear regression analysis

\begin{tabular}{|c|c|c|c|c|c|}
\hline \multirow[t]{2}{*}{ Variable } & \multicolumn{2}{|c|}{$\begin{array}{c}\text { Unstandardized } \\
\text { coefficients } \\
\end{array}$} & \multirow{2}{*}{\begin{tabular}{|c|}
$\begin{array}{l}\text { Standardized } \\
\text { coefficients }\end{array}$ \\
Beta \\
\end{tabular}} & \multirow[t]{2}{*}{$\mathbf{t}$} & \multirow[t]{2}{*}{ P-value } \\
\hline & B & Std.Error & & & \\
\hline (Constant) & 3.809 & 1.004 & - & 3.796 & .000 \\
\hline SRH & -.581 & .097 & -.255 & -5.996 & .000 \\
\hline ADL & -.100 & .025 & -.166 & -3.932 & .000 \\
\hline Age & .009 & .011 & .034 & .815 & .415 \\
\hline Sex & -.298 & .184 & -.075 & -1.620 & .106 \\
\hline Marital status & -.030 & .165 & -.008 & -.184 & .854 \\
\hline $\begin{array}{c}\text { Ability of read } \\
\text { and write }\end{array}$ & -.215 & .151 & -.056 & -1.430 & .153 \\
\hline Employment status & -1.055 & .340 & -.122 & -3.101 & .002 \\
\hline $\begin{array}{ll}\mathrm{F}=17.96 & \mathrm{R}=0.42 \\
\mathrm{P}<.001 & \mathrm{R} 2=0.18\end{array}$ & & & & & \\
\hline
\end{tabular}

\section{The validity of the Charlson Comorbidity Index}

To assess the validity of the CCI in the present study, criterion validity, including concurrent and predictive validity, was used.

\section{Concurrent validity}

To investigate concurrent validity, the SRH was used. The results of the study demonstrated a negative significant association between the CCI and SRH $(r=-0.37, p<0.001)$.

\section{Predictive validity}

The ADL was applied to assess the predictive validity of the CCI. Considering the relationship between the CCI and ADL, the results illustrated that there is a negative correlation between them $(r=-0.34$, $\mathrm{p} \leq$ 0.05). Therefore, high scores of the CCI was associated with low scores in the ADL. This means that older adults who had a higher comorbidity score showed greater levels of dependency. Indeed, the results of criterion validity using multiple linear regression revealed that the CCI is significantly pre- 
dicted by SRH (Beta $=-0.26, \mathrm{p}<0.001)$ and ADL $($ Beta $=-0.17, p<0.001)$ after adjusting the age, sex, marital status, ability to read and write, and employment. These results are shown in Table 3.

\section{Reliability of Charlson Comorbidity Index}

The results showed no variations in the number of diseases based on the CCI between the question- naires completed for the first time and 20 days later. Almost all of the subjects who had comorbidity were stable or had little reported changes. Test-retest was used and results showed a significant relationship $(\mathrm{r}=$ $0.64, \mathrm{P}<0.001)$. Indeed, to confirm the reliability of the $\mathrm{CCI}$, intra-class Correlation Coefficient (ICC) was used and was found to be 0.77 with a $95 \% \mathrm{CI}$ of 0.60 , 0.87 . Table 4 presents the results of the Intra-class Correlation Coefficient.

Table 4. Intra-class Correlation Coefficient of the CCI after 20 days

\begin{tabular}{|c|c|c|c|c|c|c|}
\hline & \multirow{2}{*}{$\begin{array}{l}\text { Intra-class } \\
\text { Correlation }\end{array}$} & \multicolumn{2}{|c|}{$\begin{array}{c}\text { 95\% Confidence } \\
\text { Interval } \\
\end{array}$} & \multicolumn{3}{|c|}{ F Test with True Value } \\
\hline & & $\begin{array}{l}\text { Lower } \\
\text { Bound }\end{array}$ & $\begin{array}{l}\text { Upper } \\
\text { Bound }\end{array}$ & Value & df1 & P-Value \\
\hline $\begin{array}{r}\text { Average } \\
\text { Measures }\end{array}$ & 0.77 & 0.60 & 0.87 & 4.40 & 50 & 0.001 \\
\hline
\end{tabular}

\section{DISCUSSION}

This study was conducted to investigate the validity and reliability of the CCI in Iranian community-dwelling older adults. Comorbidity indexes recognize the present concurrent diseases and subsequently perform weights or (pathophysiologic) intensity of these diseases. The CCI is the most extensively studied comorbidity index in predicting mortality (42).

The findings of the present study confirmed the validity and reliability of the $\mathrm{CCI}$ as a measure of health status among Iranian community-dwelling older adults. For this purpose, criterion validity and test-retest methods were used to measure the reliability. According to the study results, the association of the CCI with the SRH and ADL is a good evidence for the criterion validity of the CCI among Iranian community-dwelling older adults. In this regard, several studies have reported and confirmed the validity of the CCI, too $(19,44)$. For example, the results of the Ching-Chieh Yang et.al study showed that higher comorbidity index scores were associated with poor survival (43).

Although some studies explained that the CCI cannot predict long-term mortality in older adults and is insufficient to quantify the health status, the $\mathrm{CCI}$ easily computes any clinical setting without any extra variables because it is based on a contributor's medical history (44).

To our knowledge, despite the widespread use of the CCI, this index was commonly criticized for its lack of consideration of functional effects of comorbidity. In the present study, the use of ADL can compensate for this deficiency. Indeed, this is the first study to investigate the validity and reliability of the CCI in Iran. The current study, with its large representative sample of community-dwelling older adults living in Tehran, is the first study to examine the validity, and can be considered as an attempt to investigate the validity and reliability of the CCI in Iran. However, in other countries, several studies have been conducted in this area (45). In this regard, Frenkel et al. in the Prospective Cohort Study confirmed the validation of the Charlson comorbidity Index with ADL in acutely hospitalized elderly adults. Their results showed that the CCI is a good index for predictive mortality (46).

Database studies using the CCI have several advantages over other research designs. Populationbased research includes all patients in a geographic region and provides more accurate estimates of incidence or prevalence and may be more generalizable and relevent to health policy decision making $(24,44)$. 


\section{CONCLUSION}

The results of this study showed that the CCI has a good validity and reliability among Iranian community-dwelling older adults. This index is easyto-use and can predict functionality power of older adults in daily living activities.

Researchers and clinicians can utilize it as a valid and reliable index in clinical settings without any extra variables.

\section{Limitations}

There were some limitations to the present study. Firstly, the present study was cross-sectional, and as a result, the risk of mortality was not investigated. Secondly, it was conducted in just one city. However, considering the multicultural environment of Tehran, the results can be generalized; however, the generalization of the results for other cities requires further investigations. Thirdly, in older adults, the measurement of comorbidity alone is inadequate and the measurement of frailty is also very important.

Despite the above-mentioned limitations, the $\mathrm{CCI}$ is an objective index that is regarded as a good indicator of health investigation in community-dwelling older adults. Based on illnesses categorization and its burden, it is easy to use and compute, and costeffective for clinical settings related to older adults.

\section{Conflict of interest}

The authors declare no conflict of interest.

\section{Acknowledgments}

This study was supported by grant No 1690 at the University of Social Welfare \& Rehabilitation Sciences. The authors wish to thank the University of Social and Welfare Sciences, ethics committee and all of the community-dwelling older adults who participated in the present project. 


\section{References}

1. Nations U. World Population Ageing 2017Highlights. Department of Economic and Social Affairs. 2017.

2. Bloom DE, Canning D, Fink G. Implications of population ageing for economic growth. Oxford Rev Econ Pol 2010;26(4):583-612.

https://doi.org/10.1093/oxrep/grq038

3. Noroozian M. The elderly population in Iran: an ever growing concern in the health system. Iran J Psychiatry Behav Sci 2012;6(2):1-6.

4. Afshar PF, Asgari P, Shiri M, et al. A review of the Iran's elderly status according to the census records. Galen Med J 2016;5(1): 1-6.

5. Fuster V. Changing demographics: a new approach to global health care due to the aging population. J Am Coll Cardiol 2017; 69(24): 3002-5. https://doi.org/10.1016/j.jacc.2017.05.013

6. Organization WH. World report on ageing and health: World Health Organization; 2015.

7. Beltrán-Sánchez H, Soneji S, Crimmins EM. Past, present, and future of healthy life expectancy. Cold Spr Harb Pers. Biol 2015; 5(11): a025957. https://doi.org/10.1101/cshperspect.a025957

8. Crook T, Bartus RT, Ferris SH, et al. Age-associated memory impairment: Proposed diagnostic criteria and measures of clinical change-report of a national institute of mental health work group. Dev Neuropsychol 1986; 2(4): 261-76. https://doi.org/10.1080/87565648609540348

9. McPhee JS, French DP, Jackson D, et al. Physical activity in older age: perspectives for healthy ageing and frailty. Biogerontology 2016; 17(3): 567-80. https://doi.org/10.1007/s10522-016-9641-0
10. Charles ST, Carstensen LL. Social and emotional aging. Annu Rev Psychol 2010; 61: 383-409. https://doi.org/10.1146/annurev.psych.093008.1004 $\underline{48}$

11. Khan AR, Tahir I. Influence of Social Factors to the Quality of Life of the Elderly in Malaysia. Open Medicine Journal 2014; 1(1): 29-35. https://doi.org/10.2174/1874220301401010029

12. Chan N, Anstey KJ, Windsor TD, et al. Disability and depressive symptoms in later life: the stressbuffering role of informal and formal support. Gerontology 2011; 57(2):180-9. https://doi.org/10.1159/000314158

13. Ferreira AR, Dias CC, Fernandes L. Needs in nursing homes and their relation with cognitive and functional decline, behavioral and psychological symptoms. Front. Aging Neurosci 2016; 8(72): 1-10. https://doi.org/10.3389/fnagi.2016.00072

14. Desesquelles AF EV, Salvatore MA. Why do Italian people rate their health worse than French people do? An exploration of cross-country differentials of self-rated health. Soc Sci Med 2009; 68:1124-8.

https://doi.org/10.1016/j.socscimed.2008.12.037

15. Tiernan $\mathrm{CW}$ FH, Hiscox MA, Shaver SN, et al. Factors Related to Self-rated Health in Older Adults: A Clinical Approach Using the International Classification of Functioning, Disability, and Health (ICF) Model. J Geriatr Phys Ther 2019; 42(2): 86-97. https://doi.org/10.1519/JPT.0000000000000130

16. Karlamangla A, Tinetti M, Guralnik J, et al. Comorbidity in older adults: nosology of impairment, diseases, and conditions. J Gerontol A Biol Sci Med Sci 2007; 62(3): 296-300. https://doi.org/10.1093/gerona/62.3.296 
17. Council NR, Population CO. Preparing for an aging world: The case for cross-national research. National Academies Press, Washington, 2001: 1-3.

18. Roffman CE, Buchanan J, Allison GT. Charlson comorbidities index. J Physiother 2016; 62(3):171. https://doi.org/10.1016/j.jphys.2016.05.008

19. Meng Q, Xie Z, Zhang T.A single-item self-rated health measure correlates with objective health status in the elderly: a survey in suburban Beijing. Front Public Health 2014; 2(27): 1-9. https://doi.org/10.3389/fpubh.2014.00027

20. Lash TL, Mor V, Wieland D, et al. Methodology, design, and analytic techniques to address measurement of comorbid disease. J Gerontol A Biol Sci Med Sci 2019; 62(3): 281-5.

https://doi.org/10.1093/gerona/62.3.281

21. Hudon C, Fortin M, Vanasse A. Cumulative Illness Rating Scale was a reliable and valid index in a family practice context. J Clin Epidemiol 2005; 58(6): 603-8.

https://doi.org/10.1016/j.jclinepi.2004.10.017

22. Clark DO, Von MK, Saunders K, et al. A chronic disease score with empirically derived weights. Med care 1995; 33(8): 783-95.

https://doi.org/10.1097/00005650-199508000-00004

23. Quan H, Li B, Couris CM, et al. Updating and validating the Charlson comorbidity index and score for risk adjustment in hospital discharge abstracts using data from 6 countries. Am J Epidemiol 2011; 173(6): 676-82.

https://doi.org/10.1093/aje/kwq433

24. Charlson M, Wells MT, Ullman R, et al. The Charlson comorbidity index can be used prospectively to identify patients who will incur high future costs. PloS one 2014; 9(12):e112479. https://doi.org/10.1371/journal.pone.0112479

25. Romano PS, Roost LL, Jollis JG. Presentation adapting a clinical comorbidity index for use with ICD-9-CM administrative data: differing $\mathrm{p}$ https://doi.org/10.1016/0895-4356(93)90103-8
26. Charlson M, Szatrowski TP, Peterson J, Gold J. Validation of a combined comorbidity index. J Clin Epidemiol 1994; 47(11): 1245-51. https://doi.org/10.1016/0895-4356(94)90129-5

27. Niakan M, Paryad E, Shekholeslam F, et al. Selfcare behaviors in patients after myocardial infarction. J Holist Nurs Midwifery 2013; 23(2): 6370. (in Persian)

28. Bar B, Hemphill III JC. Charlson comorbidity index adjustment in intracerebral hemorrhage. https://doi.org/10.1161/STROKEAHA.111.617639

29. Maxwell J. Understanding and validity in qualitative research. Harv Educ Rev 1992; 62(3): 279-301. https://doi.org/10.17763/haer.62.3.83233208562518 $\underline{26}$

30. Mohajan H. Two criteria for good measurements in research: validity and reliability. Annals of Spiru Har 2017; 17(4): 59-82.

https://doi.org/10.26458/1746

31. Maisto SA, Krenek M, Chung T, et al. A comparison of the concurrent and predictive validity of three measures of readiness to change alcohol use in a clinical sample of adolescents. J stud Alcohol Drugs 2011; 72(4): 592-601. https://doi.org/10.15288/jsad.2011.72.592

32. Michael RS. Rehablitation Research, principles and application.Indiana University Bloomington 2004: 276.

33. DeVon HA, Block ME, Moyle-Wright $\mathrm{P}$, et al. A psychometric toolbox for testing validity and reliability. J Nurs Scholarsh 2007; 39(2):155-64. https://doi.org/10.1111/j.1547-5069.2007.00161.x

34. Hosseini R, Momtaz Y, Mohammadi-Shahboulaghi F, et al. Validity and reliability of Self Rated Health (SRH) measure among Iranian community-dwelling older adults. J Gerontol Geriatr 2019; 67: 103- 8.

35. Chan CS, Slaughter SE, Jones CA, et al. Greater independence in activities of daily living is associated with higher health-related quality of life scores in nursing home residents with dementia. 
Healthcare 2015, 3(3), 503-18. https://doi.org/10.3390/healthcare3030503

36. Katz S, Ford A, Moskowitz R, et al. Studies of illness in the aged. The index of ADL: a standardized measure of biological and psychosocial function. JAMA 1963; 185: 914-9.

https://doi.org/10.1001/jama.1963.03060120024016

37. Piazza JR, Charles ST, Almeida DM. Living with chronic health conditions: Age differences in affective well-being. J Gerontol B Psychol Sci Soc Sci 2007; 62(6): 313-21.

38. Taheri Tanjani P, Azadbakht M. Psychometric properties of the Persian version of the activities of daily living scale and instrumental activities of daily living scale in elderly. J Mazandaran Univ Med Sci 2016; 25(132): 103-12. (in Persian)

39. Heale R, Twycross A. Validity and reliability in quantitative studies. Evid Based Nurs 2015; 18(3): 66-7.

https://doi.org/10.1136/eb-2015-102129

40. Drost EA. Validity and reliability in social science research. Educ Res Perspect 2011; 38(1):105-23.

41. Yohannes AM, Dodd M, Morris J, et al. Reliability and validity of a single item measure of quality of life scale for adult patients with cystic fibrosis. Health Qual Life Outcomes 2011; 9(1): 105.

42. Huang Y-Q Gou R, Diao Y-s, et al. Charlson comorbidity index helps predict the risk of mortality for patients with type 2 diabetic nephropathy. J Zhejiang Univ Sci B 2014; 15(1): 58-66. https://doi.org/10.1631/jzus.B1300109

43. Yang C-C, Chen P-C, Hsu C-W, et al. Validity of the age-adjusted charlson comorbidity index on clinical outcomes for patients with nasopharyngeal cancer post radiation treatment: a 5-year nationwide cohort study. PLoS One 2015;10(1):e0117323. https://doi.org/10.1371/journal.pone.0117323

44. Testa G, Cacciatore F, Galizia G, et al. Charlson Comorbidity Index does not predict long-term mortality in elderly subjects with chronic heart failure. Age Ageing 2009; 38(6): 734-40. https://doi.org/10.1093/ageing/afp165

45. Zajacova A, Dowd JB. Reliability of self-rated health in US adults. Am J Epidemiol 2011;174(8): 977-83. https://doi.org/10.1093/aje/kwr204

46. Frenkel WJ, Jongerius EJ, Mandjes-van Uitert MJ, et al. Validation of the Charlson Comorbidity Index in acutely hospitalized elderly adults: a prospective cohort study. J Am Geriatr Soc 2014; 62(2): 342-6. https://doi.org/10.1111/igs.12635 


\title{
Validnost i pouzdanost Čarlsonovog indeksa komorbiditeta kod starije iranske populacije koja živi u uslovima zajedničkog smeštaja
}

\author{
Raziye Sadat Hosseini ${ }^{1}$, Yadollah Abolfathi Momtaz ${ }^{2,3}$, \\ Farahnaz Mohammadi Shahboulaghi ${ }^{2}$, Masoome Alijanpour Aghamaleki ${ }^{4}$
}

\begin{abstract}
${ }^{1}$ Istraživački centar za zdravstvenu negu, Fakultet za sestrinstvo i akušerstvo, Iranski univerzitet medicinskih nauka, Teheran, Islamska Republika Iran

${ }^{2}$ Iranski centar za istraživanje starenja, Univerzitet za socijalnu zaštitu i rehabilitacione nauke, Teheran, Islamska Republika Iran

${ }^{3}$ Malezijski centar za istraživanje starenja (MyAgeing), Univerzitet u Putri, Putra, Malezija ${ }^{4}$ Student postdiplomskih studija na reproduktivnom zdravlju, Univerzitet Tarbiat Modares, Teheran, Islamska Republika Iran
\end{abstract}

\section{S A ŽETAK}

Čarlsonov indeks komorbiditeta jednostavna je metoda za prikazivanje opterećenja komorbiditetom. Cilj ove studije bila je procena validnosti i pouzdanosti Čarlsonovog indeksa komorbiditeta kod starije iranske populacije u uslovima zajedničkog smeštaja.

Ova studija preseka sprovedena 2017. godine, uključila je 600 starijih osoba starosti preko 60 godina, koje su živele u uslovima zajedničkog smeštaja u Teheranu, u Iranu. Za dobijanje uzorka primenjena je višefazna metoda slučajnog uzorkovanja po klasterima. Čarlsonov indeks komorbiditeta obuhvatio je 17 kategorija bolesti i upotrebljen je kao sredstvo za merenje jednogodišnjeg rizika i opterećenja bolestima. Validnost kriterijuma procenjena je skalom za samoprocenu zdravlja i skalom za ocenu svakodnevnih aktivnosti. Za testiranje validnosti i pouzdanosti Čarlsonovog indeksa komorbiditeta korišćena je Spirmanova korelacija ranga, kao i koeficijent korelacije unutar klase, softver SPSS, verzija 23.

Od ukupno 600 ispitanika, $64 \%$ bilo je ženskog pola. Prosečna starost bila je $76,82(\mathrm{SD}=7,45)$ godine i skoro $63 \%$ ispitanika bilo je u braku. Rezultati validnosti kriterijuma, primenom analize višestruke linearne regresije, pokazali su da je Čarlsonov indeks komorbiditeta značajno predviđen primenom skale za samoprocenu zdravlja (Beta $=-0,26 ; p<0,001)$ i skalom za ocenu svakodnevnih aktivnosti $($ Beta $=-0,17$; $p<$ 0,001). Pored toga, pouzdanost Čarlsonovog indeksa komorbiditeta, primenom koeficijenta korelacije unutar klase iznosila je 0,77; 95\% CI, 0,60 do 0,87.

Kako su rezultati pokazali dobar nivo validnosti i pouzdanosti Čarlsonovog indeksa komorbiditeta, njegova primena se preporučuje u zdravstvenim studijama o starijoj populaciji, koja živi u uslovima zajedničkog smeštaja u Iranu.

Ključne reči: Čarlsonov indeks komorbiditeta, validnost kriterijuma, pouzdanost, starija populacija koja živi u uslovima zajedničkog smeštaja, Iran 